\title{
OPEN Deficiency of phyto-available sulphur, zinc, boron, iron, copper and manganese in soils of India
}

\author{
Arvind Kumar Shukla ${ }^{1}$, Sanjib Kumar Behera ${ }^{1 凶}$, Chandra Prakash ${ }^{1}$, Ajay Tripathi ${ }^{1}$, \\ Ashok Kumar Patra ${ }^{1}$, Brahma Swaroop Dwivedi ${ }^{2}$, Vivek Trivedi ${ }^{3}$, Ch. Srinivasa Rao ${ }^{4}$, \\ Suresh Kumar Chaudhari ${ }^{5}$, Soumitra Das ${ }^{6}$ \& Anil Kumar Singh ${ }^{5}$
}

Nutrient deficiencies in soil-crop contexts and inappropriate managements are the important reasons for low crop productivity, reduced nutritional quality of agricultural produce and animal/ human malnutrition, across the world. The present investigation was carried out to evaluate nutrient deficiencies of sulphur (S) and micronutrients [zinc (Zn), boron (B), iron (Fe), copper (Cu) and manganese $(\mathrm{Mn})]$ in agricultural soils of India for devising effective management strategies to achieve sustainable crop production, improved nutritional quality in crops and better animal/ human health. A total of $2,42,827$ surface $(0-15 \mathrm{~cm}$ depth) soil samples were collected from agriculture fields of 615 districts lying in 28 states of India and were analysed for available $S$ and micronutrients concentration. The study was carried out under the aegis of All India Coordinated Research Project on Micro- and Secondary-Nutrients and Pollutant Elements in Soils and Plants. The mean concentrations were $27.0 \pm 29.9 \mathrm{mg} \mathrm{kg}^{-1}$ for available $S, 1.40 \pm 1.60 \mathrm{mg} \mathrm{kg}^{-1}$ for available $\mathrm{Zn}$ and $1.40 \pm 4.70 \mathrm{mg} \mathrm{kg}^{-1}$ for available $B, 31.0 \pm 52.2 \mathrm{mg} \mathrm{kg}^{-1}$ for available $\mathrm{Fe}, 2.30 \pm 3.50 \mathrm{mg} \mathrm{kg}^{-1}$ for available $\mathrm{Cu}$ and $17.5 \pm 21.4 \mathrm{mg} \mathrm{kg}^{-1}$ for available $\mathrm{Mn}$. There were variable and widespread deficiencies of $\mathrm{S}$ and micronutrients in different states. The deficiencies (acute deficient + deficient + latent deficiency) of $\mathrm{S}$ (58.6\% of soils), $\mathrm{Zn}$ ( $51.2 \%$ of soils) and B ( $44.7 \%$ of soils) were higher compared to the deficiencies of $\mathrm{Fe}$ ( $19.2 \%$ of soils), $\mathrm{Cu}$ ( $11.4 \%$ of soils) and $\mathrm{Mn}$ ( $17.4 \%$ of soils). Out of 615 districts, $>50 \%$ of soils in 101, 131 and 86 districts were deficient in available $S$, available $Z n$ and available $B$, respectively. Whereas, $>25 \%$ of soils in 83,5 and 41 districts had deficiencies of available $\mathrm{Fe}$, available $\mathrm{Cu}$ and available $\mathrm{Mn}$, respectively. There were occurrences of 2-nutrients deficiencies such $\mathrm{S}+\mathrm{Zn}(9.30 \%$ of soils), $\mathrm{Zn}+\mathrm{B}(8.70 \%$ of soils), $\mathrm{S}+\mathrm{B}(7.00 \%$ of soils $)$ and $\mathrm{Zn}+\mathrm{Fe}(5.80 \%$ of soils $)$ to a greater extent compared to the deficiencies of $\mathrm{Zn}+\mathrm{Mn}$ ( $3.40 \%$ of soils), $\mathrm{S}+\mathrm{Fe}$ (3.30\% of soils), $\mathrm{Zn}+\mathrm{Cu}(2.80 \%$ of soils) and $\mathrm{Fe}+\mathrm{B}(2.70 \%$ of soils). Relatively lower $\%$ of soils were deficient in 3-nutrients (namely $S+Z n+B, S+Z n+B$ and $Z n+F e+B$ ), 4-nutrients (namely $Z n+F e+C u+M n$ ) and 5-nutrients (namely $\mathrm{Zn}+\mathrm{Fe}+\mathrm{Cu}+\mathrm{Mn}+\mathrm{B}$ ) simultaneously. The information regarding the distribution of deficiencies of $\mathrm{S}$ and micronutrients (both single and multi-nutrients) could be used by various stakeholders for production, supply and application of right kind of fertilizers in different districts, states and agroecological regions of India for better crop production, crop nutritional quality, nutrient use efficiency, soil health and for tackling human and animal malnutrition.

Soil is linked to wellness of human being and animals via agriculture and produces obtained from agriculture ${ }^{1}$. Crop plants take desired nutrients, primarily from soil, for their growth and development ${ }^{2-4}$. The deficiency of phyto-available (hereafter referred as available) nutrients in soils adversely affect soil health, crop production, nutritional quality of agricultural produces and in turn human/animal health ${ }^{5,6}$. Along with deficiencies of macronutrients namely, nitrogen $(\mathrm{N})$, phosphorus $(\mathrm{P})$ and potassium $(\mathrm{K})$ deficiency, several researchers of the world reported the deficiency of micronutrients (zinc $(\mathrm{Zn})$, boron $(\mathrm{B})$, iron $(\mathrm{Fe})$, copper $(\mathrm{Cu})$ and manganese $(\mathrm{Mn})$ ) and sulphur $(\mathrm{S})$ in various soils under cultivation ${ }^{7-11}$. The appearance of deficiencies of micronutrients

${ }^{1}$ ICAR-Indian Institute of Soil Science, Bhopal, Madhya Pradesh 462038, India. ${ }^{2}$ ICAR-National Bureau of Soil Survey and Land Use Planning, Nagpur, Maharashtra 440033, India. ${ }^{3}$ ICAR-Indian Agricultural Research Institute, New Delhi 110012, India. ${ }^{4}$ ICAR-National Academy of Agricultural Research Management, Hyderabad, Telangana 500030, India. ${ }^{5}$ Indian Council of Agricultural Research, New Delhi 110012, India. ${ }^{6}$ International Zinc Association, New Delhi 110062, India. ${ }^{\circledR}$ email: sanjibkumarbehera123@gmail.com 
in different soils is mainly due to enhanced cropping intensity, high-yielding cultivars of various crops, increase used NPK fertilisers with nil or less micronutrients contents, nil or very less application of organic manures and better soil and plant analysis technologies ${ }^{12}$. The proportion of deficiencies of $\mathrm{S}$ and micronutrients in different arears such as different districts and states of a country is different due to differences in soils, climates, crops and crop management options ${ }^{5,13}$. Soils with micronutrients deficiencies produce crops with low concentration of micronutrients ${ }^{11,14}$. Consumption of foods obtained from such crops lead to poor health of animal and human, because of micronutrients malnutrition. However, effective management of micronutrients, namely soil and foliar application of micronutrients, in various soil-crop situations could help in alleviating micronutrients deficiency in soils and crops, enhancing crop production and crop quality and reducing micronutrients malnutrition in animals and human being ${ }^{15}$.

The results of continuous assessment of the status of available $S$ and micronutrients and their deficiencies in different cultivated soils help the policy makers and fertilizer industries for planning production and supply of fertilizers having $S$ and micronutrients to districts and states for effective management of these nutrients ${ }^{11,16}$. The geostatistical tools are useful for preparation of S and micronutrients deficiency maps of different areas ${ }^{17,18,19}$. The deficiency maps are helpful in preparing strategies for efficient $S$ and micronutrients management with due emphasis on right nutrient, amount, form and place of application. This helps in better crop production, crop produce quality and soil health ${ }^{1,6,20,21}$.

The information pertaining to state-wise status and deficiency of available $\mathrm{S}$ and micronutrients in different states of India is limited, although there are some scattered reports on this aspect. It was hypothesized that there is a wide variability of status and deficiency of available $S$ and micronutrients in cultivated soils of different states of India. The present study was, therefore, carried out to assess the concentrations of available $\mathrm{S}$ and micronutrients and levels and distribution of their deficiencies in cultivated soils of various states of India. The results obtained from the study could be highly useful for effective $S$ and micronutrients management in different soil-crop situations of various states of the country.

\section{Materials and methods}

Study area. The study location viz., India is located at $8^{\circ} 4^{\prime}$ to $37^{\circ} 6^{\prime} \mathrm{N}$ latitude and $68^{\circ} 7^{\prime}$ to $97^{\circ} 25^{\prime} \mathrm{E}$ longitude and surrounded by the Indian Ocean (on the south), the Arabian Sea (on the southwest), and the Bay of Bengal (on the southeast). It shares its land borders with Pakistan, China, Bhutan, Bangladesh, Myanmar and Nepal. India is the bulk of Indian subcontinent lying on Indian tectonic plate which is a portion of IndoAustralian plate. It comprises of 28 states and 8 union territories. Soils of the country are alluvial, black, red and yellow, lateritic, arid, forest and mountainous, and are formed by deposition of sediments of rivers. Soils belong to mainly Inceptisols, Alfisols, Entisols, Vertisols, Mollisols, Aridisols, Ultisols and Oxisols orders with sandy to clayey in texture ${ }^{22}$. The climate of the country is influenced by the Himalayas and the Thar desert. India has arid, semi-arid, tropical wet, tropical wet-dry, humid sub-tropical and alpine climatic zones with mean temperature of $<20.0$ to $>27.5^{\circ} \mathrm{C}$ prevailing across the country. The country is divided into 20 agro-ecological regions (AER) with different climate parameters, soils and cultivated $\operatorname{crops}^{23}$ (Supplementary Tables S1, S2). The mean annual rainfall varies from $<150$ to $3000 \mathrm{~mm}$ in different AERs. It receives uneven and erratic rainfall during June to September months. It rains heavily in north-eastern and Western Ghats regions and Kerala state of the country. Whereas, south-eastern parts and Indo-Gangetic plain receives moderate rainfall. Scanty rainfall is obtained in the western parts of Gujarat, Rajasthan, Punjab and Haryana.

Soil sampling and analysis. A total of $2,42,827$ soil samples from the surface $(0-15 \mathrm{~cm}$ depth) soil layers were collected from agricultural land holdings of 615 districts lying in 28 states of India, under the tutelage of All India Coordinated Research Project on Micro and Secondary Nutrients and Pollutant Elements in Soils and Plants, by following stratified random sampling procedure ${ }^{24}$, during April to June months of 2012-2018. Soil samples were collected using a hand-held auger made up of stainless-steel. The geographical coordinates of each sampling point were recorded using Global Positioning System. Each composite soil sample was obtained from 3 to 4 subsamples collected from a small land holding $(<1$ ha), 6-7 subsamples collected from a medium land holding (1-3 ha) and 9-10 subsamples collected from a large land holding (>3 ha), of each district. The collected samples were air dried, processed, ground to pass through a $2 \mathrm{~mm}$ size sieve and stored in plastic bottles for analysis.

The analysis of soil samples was carried out for available S using calcium chloride solution $(0.15 \%)$ as extractant ${ }^{25}$ and spectrophotometer (Make (model): Shimadzu (UV-1800)). Available Zn, Fe, Cu and Mn in soil samples were determined after extracting the samples with diethylene triamine penta acetic acid extractant ${ }^{26}$. The estimation of $\mathrm{Zn}, \mathrm{Fe}, \mathrm{Cu}$ and $\mathrm{Mn}$ in clear extract was carried out utilizing atomic absorption spectrophotometer (Make (model): Varian (AA240FS)). Available B was estimated after extracting the samples with hot water ${ }^{27}$ and estimating the colour intensity developed by adding azomethine-H solution using a spectrophotometer (Make (model): Shimadzu (UV-1800)).

Statistical analysis. The dataset related to available $\mathrm{S}, \mathrm{Zn}, \mathrm{B}, \mathrm{Fe}, \mathrm{Cu}$ and $\mathrm{Mn}$ in soil samples were subjected to statistical analysis for obtaining descriptive statistics viz., minimum, maximum, mean, standard deviation (SD), coefficient of variation (CV), skewness and kurtosis, using SAS 9.2 software package ${ }^{28}$. The frequency distribution of soil samples having available $S$ and micronutrients in different concentrations and distribution of single- and multi-nutrients deficiencies were estimated using data analysis programme of Microsoft-excel. The concentrations of S and micronutrients in soil samples were categorized as acute deficient, deficient, latent deficient, marginally sufficient, adequate and high as per the generalized classification adopted for Indian soils ${ }^{13}$ (Table 1). The distribution maps for two and multi-nutrients deficiencies were prepared using ArcGIS software 


\begin{tabular}{|l|l|l|l|l|l|l|}
\hline Nutrients & Acute deficient & Deficient & Latent deficient & Marginal sufficient & Adequate & High \\
\hline Available $\mathrm{S}\left(\mathrm{mg} \mathrm{kg}^{-1}\right)$ & $\leq 7.50$ & $>7.50-\leq 15.0$ & $>15.0-\leq 22.5$ & $>22.5-\leq 30.0$ & $>30.0-\leq 40.0$ & $>40.0$ \\
\hline Available $\mathrm{Zn}\left(\mathrm{mg} \mathrm{kg}^{-1}\right)$ & $\leq 0.30$ & $>0.30-\leq 0.60$ & $>0.60-\leq 0.90$ & $>0.90-\leq 1.20$ & $>1.20-\leq 1.80$ & $>1.80$ \\
\hline Available B $\left(\mathrm{mg} \mathrm{kg}^{-1}\right)$ & $\leq 0.20$ & $>0.20-\leq 0.50$ & $>0.50-\leq 0.70$ & $>0.70-\leq 0.90$ & $>0.90-\leq 1.10$ & $>1.10$ \\
\hline Available Fe $\left(\mathrm{mg} \mathrm{kg}^{-1}\right)$ & $\leq 2.50$ & $>2.50-\leq 4.50$ & $>4.50-\leq 6.50$ & $>6.50-\leq 8.50$ & $>8.50-\leq 10.5$ & $>10.5$ \\
\hline Available $\mathrm{Cu}\left(\mathrm{mg} \mathrm{kg}^{-1}\right)$ & $\leq 0.20$ & $>0.20-\leq 0.40$ & $>0.40-\leq 0.60$ & $>0.60-\leq 0.80$ & $>0.80-\leq 1.00$ & $>1.00$ \\
\hline Available $\mathrm{Mn}\left(\mathrm{mg} \mathrm{kg}^{-1}\right)$ & $\leq 1.00$ & $>1.00-\leq 3.00$ & $>3.00-\leq 5.00$ & $>5.00-\leq 7.00$ & $>7.00-\leq 9.00$ & $>9.00$ \\
\hline
\end{tabular}

Table 1. Critical limits of available $S$ and micronutrients for agricultural soils of India.

\begin{tabular}{|c|c|c|c|c|c|c|}
\hline State & Acute deficient & Deficient & Latent deficient & Marginal sufficient & Adequate & High \\
\hline Andhra Pradesh & 7.70 & 28.4 & 12.4 & 16.2 & 9.20 & 26.1 \\
\hline Arunachal Pradesh & 1.00 & 5.00 & 7.20 & 29.6 & 56.7 & 0.50 \\
\hline Assam & 6.20 & 30.2 & 29.4 & 22.7 & 6.30 & 5.30 \\
\hline Bihar & 8.40 & 36.2 & 25.5 & 15.8 & 7.80 & 6.30 \\
\hline Chhattisgarh & 9.40 & 27.9 & 17.8 & 27.8 & 11.2 & 6.00 \\
\hline Goa & 0.00 & 53.2 & 7.50 & 5.10 & 11.0 & 23.1 \\
\hline Gujarat & 17.4 & 45.1 & 16.7 & 10.1 & 5.10 & 5.60 \\
\hline Haryana & 22.9 & 17.2 & 7.50 & 5.60 & 5.30 & 41.5 \\
\hline Himachal Pradesh & 0.90 & 3.60 & 3.20 & 10.6 & 47.4 & 34.3 \\
\hline Jammu \& Kashmir & 15.0 & 12.9 & 9.80 & 12.1 & 17.8 & 32.6 \\
\hline Jharkhand & 17.8 & 47.3 & 15.6 & 8.60 & 6.80 & 3.80 \\
\hline Karnataka & 16.1 & 30.5 & 16.5 & 17.1 & 10.3 & 9.50 \\
\hline Kerala & 31.4 & 18.0 & 12.5 & 13.7 & 9.50 & 14.9 \\
\hline Madhya Pradesh & 14.7 & 37.7 & 19.4 & 13.4 & 7.10 & 7.70 \\
\hline Maharashtra & 5.20 & 37.2 & 23.5 & 13.0 & 10.5 & 10.7 \\
\hline Manipur & 12.3 & 41.7 & 5.20 & 5.50 & 21.7 & 13.4 \\
\hline Meghalaya & 8.10 & 10.9 & 40.8 & 28.9 & 10.1 & 1.20 \\
\hline Mizoram & 10.8 & 11.3 & 27.4 & 41.2 & 9.30 & 0.00 \\
\hline Nagaland & 5.60 & 11.4 & 17.5 & 50.2 & 12.3 & 3.00 \\
\hline Odisha & 29.5 & 22.8 & 14.9 & 12.3 & 9.30 & 11.2 \\
\hline Punjab & 15.9 & 20.1 & 14.2 & 15.7 & 13.0 & 21.1 \\
\hline Rajasthan & 33.9 & 27.3 & 17.0 & 12.0 & 4.90 & 4.80 \\
\hline Tamil Nadu & 3.20 & 13.3 & 13.3 & 16.5 & 15.3 & 38.5 \\
\hline Telangana & 11.1 & 31.5 & 17.2 & 15.3 & 12.3 & 12.6 \\
\hline Tripura & 14.6 & 16.3 & 6.20 & 18.5 & 38.8 & 5.60 \\
\hline Uttar Pradesh & 11.4 & 29.4 & 20.8 & 19.2 & 12.8 & 6.50 \\
\hline Uttarakhand & 12.8 & 25.9 & 13.7 & 13.2 & 9.10 & 25.3 \\
\hline West Bengal & 28.6 & 32.9 & 17.0 & 12.3 & 5.10 & 4.00 \\
\hline India & 11.4 & 29.4 & 17.8 & 12.1 & 11.6 & 17.7 \\
\hline
\end{tabular}

Table 2. State-wise deficiency (\% of soil samples) status of available $\mathrm{S}$.

(version 10.5.1) (Environmental Systems Research Institute, Redlands, California) for power BI, in order to have better data visualization and proper understanding of distribution of nutrient deficiencies in different parts of India. The nutrient deficiencies (\% of the soil samples), district boundary, state boundary and AER boundary were used as different layers of ArcGIS mapping. Two kriged distribution maps of $\mathrm{Zn}+\mathrm{B}$ and $\mathrm{S}+\mathrm{Zn}+\mathrm{B}$ deficiency (considering deficient (acute deficient + deficient + latent deficient), marginal (marginally sufficient) and high (adequate + high) status) were prepared using ArcGIS software (version 10.5.1) (Environmental Systems Research Institute, Redlands, California).

Consent to participate. The consent of all the participants of the study was obtained.

Consent for publication. The consent for publication was obtained from all the participants of the study. 


\begin{tabular}{|l|c|l|l|l|l|l|}
\hline State & Acute deficient & Deficient & Latent deficient & Marginal sufficient & Adequate & High \\
\hline Andhra Pradesh & 3.40 & 27.6 & 19.8 & 14.3 & 16.9 & 17.9 \\
\hline Arunachal Pradesh & 0.30 & 6.10 & 4.80 & 7.90 & 26.2 & 54.8 \\
\hline Assam & 3.00 & 39.6 & 18.6 & 13.8 & 11.4 & 13.6 \\
\hline Bihar & 9.10 & 29.4 & 14.5 & 14.0 & 15.2 & 17.7 \\
\hline Chhattisgarh & 6.60 & 30.5 & 18.5 & 17.8 & 15.0 & 11.7 \\
\hline Goa & 23.5 & 35.0 & 11.9 & 11.5 & 15.0 & 3.10 \\
\hline Gujarat & 7.70 & 36.6 & 16.3 & 14.5 & 13.2 & 11.8 \\
\hline Haryana & 2.10 & 18.4 & 11.0 & 14.7 & 20.7 & 33.1 \\
\hline Himachal Pradesh & 1.20 & 8.30 & 5.80 & 7.10 & 20.7 & 56.9 \\
\hline Jammu \& Kashmir & 4.40 & 24.8 & 12.7 & 14.3 & 18.4 & 25.3 \\
\hline Jharkhand & 2.20 & 19.9 & 17.8 & 19.5 & 20.4 & 20.2 \\
\hline Karnataka & 11.4 & 27.0 & 12.1 & 10.9 & 13.4 & 25.2 \\
\hline Kerala & 3.80 & 5.90 & 4.70 & 7.10 & 12.2 & 66.3 \\
\hline Madhya Pradesh & 20.3 & 46.7 & 15.9 & 7.30 & 5.70 & 4.20 \\
\hline Maharashtra & 9.90 & 35.7 & 13.0 & 11.5 & 14.8 & 15.1 \\
\hline Manipur & 5.70 & 19.9 & 12.5 & 17.2 & 23.5 & 21.3 \\
\hline Meghalaya & 0.20 & 5.60 & 6.80 & 8.90 & 18.9 & 59.6 \\
\hline Mizoram & 0.00 & 3.50 & 5.10 & 6.90 & 29.4 & 55.1 \\
\hline Nagaland & 0.10 & 6.60 & 7.60 & 7.40 & 25.2 & 53.2 \\
\hline Odisha & 13.5 & 27.4 & 13.7 & 13.9 & 14.7 & 16.9 \\
\hline Punjab & 4.20 & 19.0 & 12.1 & 12.6 & 18.8 & 33.4 \\
\hline Rajasthan & 22.6 & 41.7 & 15.6 & 8.70 & 6.00 & 5.30 \\
\hline Tamil Nadu & 7.50 & 23.1 & 14.4 & 15.4 & 17.5 & 22.0 \\
\hline Telangana & 5.80 & 32.2 & 16.8 & 19.3 & 14.1 & 11.9 \\
\hline Tripura & 0.60 & 3.90 & 0.60 & 2.80 & 19.7 & 72.5 \\
\hline Uttar Pradesh & 4.00 & 34.6 & 22.0 & 17.3 & 15.0 & 7.20 \\
\hline Uttarakhand & 1.60 & 9.70 & 7.50 & 11.1 & 18.9 & 51.2 \\
\hline West Bengal & 2.90 & 14.3 & 13.6 & 18.7 & 26.2 & 24.2 \\
\hline India & 7.90 & 28.6 & 14.7 & 12.7 & 14.8 & 21.3 \\
\hline & & & & & & \\
\hline
\end{tabular}

Table 3. State-wise deficiency (\% of soil samples) status of available $\mathrm{Zn}$.

\section{Results}

Status of available $\mathbf{S}$ and micronutrients. The values of available $\mathrm{S}$ and micronutrients varied widely (Supplementary Table S3). The mean concentration (mean \pm SD) was $27.0 \pm 29.9 \mathrm{mg} \mathrm{kg}^{-1}$ for available S, $1.40 \pm 1.60 \mathrm{mg} \mathrm{kg}^{-1}$ for available $\mathrm{Zn}, 1.40 \pm 4.70 \mathrm{mg} \mathrm{kg}^{-1}$ for available $\mathrm{B}, 31.0 \pm 52.2 \mathrm{mg} \mathrm{kg}^{-1}$ for available $\mathrm{Fe}$, $2.30 \pm 3.50 \mathrm{mg} \mathrm{kg}^{-1}$ for available $\mathrm{Cu}$, and $17.5 \pm 21.4 \mathrm{mg} \mathrm{kg}^{-1}$ for available $\mathrm{Mn}$. The $\mathrm{CV}$ values of available $\mathrm{S}$ and micronutrients varied from 111 to $338 \%$.

Single nutrient deficiencies of available $\mathbf{S}$ and micronutrients. On average, about 11.4, 29.4 and $17.8 \%$ of soils were acute deficient, deficient and latent deficient in available S (Table 2). Whereas, 12.1, 11.6 and $17.7 \%$ of soils were marginally sufficient, adequate and high, respectively, in available S. Relatively, the higher $\%$ of soils in the states namely Haryana (22.9\%), Kerala (31.4\%), Odisha (29.5\%), Rajasthan (33.9\%) and West Bengal (28.6\%) were acute deficient in available S. More than $60 \%$ of soils in the states namely, Assam, Bihar, Goa, Gujarat, Jharkhand, Karnataka, Kerala, Madhya Pradesh, Maharashtra, Odisha, Rajasthan, Uttar Pradesh and West Bengal were deficient (including acute deficient, deficient and latent deficient) in available S.

Averagely, about 7.90, 28.6 and $14.7 \%$ of soils were acute deficient, deficient and latent deficient in available $\mathrm{Zn}$ (Table 3 ). Whereas, $12.7,14.8$ and $21.3 \%$ of soils were marginally sufficient, adequate and high, respectively, in available $\mathrm{Zn}$. Relatively, the higher \% of soils in the states namely Goa (23.5\%), Karnataka (11.4\%), Madhya Pradesh (20.3\%), Rajasthan (22.6\%), Odisha (13.5\%), Bihar (9.10\%) and Maharashtra (9.90\%) were acute deficient in available $\mathrm{Zn}$. More than $50 \%$ of soils in the states namely, Andhra Pradesh, Assam, Bihar, Chhattisgarh, Goa, Gujarat, Karnataka, Madhya Pradesh, Maharashtra, Odisha, Rajasthan, Telangana and Uttar Pradesh were deficient (including acute deficient, deficient and latent deficient) in available $\mathrm{Zn}$.

On average, about $4.00,19.2$ and $21.5 \%$ of soils were acute deficient, deficient and latent deficient in available B (Table 4). Whereas, $12.1,11.4$ and $31.7 \%$ of soils were marginally sufficient, adequate and high, respectively, in available B. Relatively, the higher \% of soils in the states namely Gujarat (18.7\%), Jammu \& Kashmir (12.1\%), Kerala (30.5), Odisha (18.2\%), and West Bengal (13.1\%) were acute deficient in available B. More than $60 \%$ of soils in the states namely Arunachal Pradesh, Assam, Bihar, Gujarat, Himachal Pradesh, Jammu \& Kashmir, Jharkhand, Kerala, Maharashtra, Manipur, Meghalaya, Mizoram, Nagaland, Odisha and West Bengal were deficient (including acute deficient, deficient and latent deficient) in available B. 


\begin{tabular}{|l|l|l|l|l|l|c|}
\hline State & Acute deficient & Deficient & Latent deficient & Marginal sufficient & Adequate & High \\
\hline Andhra Pradesh & 0.60 & 10.5 & 16.4 & 24.9 & 17.0 & 30.6 \\
\hline Arunachal Pradesh & 1.20 & 37.9 & 50.1 & 6.50 & 2.60 & 1.60 \\
\hline Assam & 8.10 & 38.4 & 29.7 & 12.7 & 2.80 & 8.4 \\
\hline Bihar & 6.80 & 32.2 & 24.4 & 16.4 & 9.70 & 10.5 \\
\hline Chhattisgarh & 3.40 & 19.7 & 11.8 & 11.7 & 9.40 & 43.9 \\
\hline Goa & 0.00 & 12.9 & 29.1 & 13.7 & 12.9 & 31.3 \\
\hline Gujarat & 18.7 & 38.4 & 12.9 & 8.70 & 5.40 & 15.9 \\
\hline Haryana & 0.20 & 3.30 & 5.60 & 7.9 & 10.5 & 72.4 \\
\hline Himachal Pradesh & 3.60 & 28.9 & 44.8 & 13.5 & 5.10 & 4.10 \\
\hline Jammu \& Kashmir & 12.1 & 24.0 & 23.9 & 12.9 & 11.8 & 15.3 \\
\hline Jharkhand & 8.10 & 41.8 & 25.0 & 11.6 & 6.30 & 7.20 \\
\hline Karnataka & 2.20 & 33.7 & 21.5 & 10.5 & 6.10 & 26.0 \\
\hline Kerala & 30.5 & 25.0 & 12.3 & 7.80 & 6.00 & 18.4 \\
\hline Madhya Pradesh & 0.40 & 5.70 & 7.60 & 8.20 & 6.30 & 71.8 \\
\hline Maharashtra & 3.40 & 28.3 & 40.3 & 13.6 & 6.00 & 8.40 \\
\hline Manipur & 8.90 & 43.4 & 20.5 & 13.0 & 7.40 & 6.80 \\
\hline Meghalaya & 1.70 & 44.3 & 31.3 & 9.80 & 6.10 & 6.70 \\
\hline Mizoram & 2.00 & 33.0 & 38.7 & 19.5 & 5.10 & 1.80 \\
\hline Nagaland & 0.10 & 51.3 & 33.8 & 6.00 & 5.30 & 3.60 \\
\hline Odisha & 18.2 & 35.8 & 18.2 & 10.0 & 5.50 & 12.3 \\
\hline Punjab & 1.20 & 14.2 & 17.1 & 14.7 & 12.1 & 40.7 \\
\hline Rajasthan & 1.30 & 6.10 & 9.90 & 13.7 & 11.0 & 58.0 \\
\hline Tamil Nadu & 3.80 & 19.8 & 13.3 & 11.3 & 8.40 & 43.4 \\
\hline Telangana & 1.80 & 30.3 & 27.3 & 16.1 & 9.40 & 15.0 \\
\hline Tripura & 1.70 & 15.7 & 30.9 & 27.5 & 16.3 & 7.90 \\
\hline Uttar Pradesh & 1.00 & 19.5 & 19.3 & 16.2 & 12.0 & 32.0 \\
\hline Uttarakhand & 6.10 & 18.0 & 10.3 & 7.80 & 8.80 & 49.0 \\
\hline West Bengal & 13.1 & 29.4 & 22.2 & 12.6 & 7.80 & 14.9 \\
\hline India & 4.00 & 19.2 & 21.5 & 12.1 & 11.4 & 31.7 \\
\hline & & & & & & \\
\hline
\end{tabular}

Table 4. State-wise deficiency (\% of soil samples) status of available B.

Averagely, about $3.80,9.00$ and $6.40 \%$ of soils were acute deficient, deficient and latent deficient in available Fe (Table 5). Whereas, 9.60, 11.3 and $59.9 \%$ of soils were marginally sufficient, adequate and high, respectively, in available Fe. Relatively, the higher \% of soils in the states namely Haryana (8.20\%), Karnataka (8.90\%), Maharashtra (8.50), Rajasthan (5.70\%), Tamil Nadu (6.00\%), Telangana (5.00\%) and Uttar Pradesh (5.40\%) were acute deficient in available Fe. More than 25\% of soils in the states namely, Andhra Pradesh, Goa, Gujarat, Haryana, Karnataka, Maharashtra, Rajasthan, Tamil Nadu and Telangana were deficient (including acute deficient, deficient and latent deficient) in available Fe.

Averagely, about $2.10,2.10$ and $7.20 \%$ of soils were acute deficient, deficient and latent deficient in available $\mathrm{Cu}$ (Table 6). Whereas, 10.8, 10.2 and $67.6 \%$ of soils were marginally sufficient, adequate and high, respectively, in available $\mathrm{Cu}$. Relatively, the higher \% of soils in the states namely Haryana (6.20\%), Odisha (5.70\%). Punjab (4.70), Rajasthan (9.10\%), and Uttar Pradesh (3.10\%) were acute deficient in available Cu. More than $25 \%$ of soils in the states namely, Goa, Haryana, Punjab, Rajasthan, and Uttar Pradesh were deficient (including acute deficient, deficient and latent deficient) in available $\mathrm{Cu}$.

On average, about 1.10, 6.00 and $10.3 \%$ of soils were acute deficient, deficient and latent deficient in available Mn (Table 7). Whereas, $13.2,9.10$ and $60.4 \%$ of soils were marginally sufficient, adequate and high, respectively, in available Mn. Relatively, the higher \% of soils in the states namely Jammu \& Kashmir (3.50\%), Kerala (3.40\%), Punjab (7.80), and Rajasthan (5.80\%) were acute deficient in available Mn. More than $20 \%$ of soils in the states namely, Bihar, Goa, Haryana, Jammu \& Kashmir, Kerala, Nagaland, Punjab, Rajasthan, Tamil Nadu and Uttar Pradesh were deficient (including acute deficient, deficient and latent deficient) in available Mn.

Multi-nutrients deficiencies of available $\mathbf{S}$ and micronutrients. The mean deficiency of 2 or $>2$-nutrients deficiency of available $\mathrm{S}$ and micronutrients varied from $0.10 \%(\mathrm{Zn}+\mathrm{Fe}+\mathrm{Cu}+\mathrm{Mn}+\mathrm{B})$ to $9.30 \%$ $(\mathrm{S}+\mathrm{Zn})($ Table 8$)$. The deficiency of $\mathrm{S}+\mathrm{Zn}$ was predominantly prevalent in different districts of Bihar, Gujarat, Karnataka, Madhya Pradesh, Odisha, Rajasthan, Uttar Pradesh and Maharashtra (Supplementary Figure S1). More than 20\% of soils in 9 districts of Gujarat, 25 districts of Madhya Pradesh, 8 districts of Odisha and 10 districts of Rajasthan were deficient in S $\mathrm{Zn}$. The deficiency of $\mathrm{Zn}+\mathrm{B}$ varied from 0.60 to $20.3 \%$ of soils in different states with mean value of $8.70 \%$. It's prevalence in states like Bihar, Karnataka, Odisha and Tamil Nadu was higher (Fig. 1, Supplementary Figure S2). More than 20\% of the sampled sites in 16 districts of Bihar, 5 districts 


\begin{tabular}{|l|l|l|l|l|l|l|}
\hline State & Acute deficient & Deficient & Latent deficient & Marginal sufficient & Adequate & High \\
\hline Andhra Pradesh & 3.80 & 11.9 & 12.1 & 11.8 & 7.70 & 52.6 \\
\hline Arunachal Pradesh & 0.00 & 0.40 & 11.2 & 17.0 & 12.7 & 58.7 \\
\hline Assam & 0.10 & 0.10 & 0.00 & 0.00 & 0.30 & 99.5 \\
\hline Bihar & 1.60 & 5.30 & 4.00 & 5.60 & 5.20 & 78.3 \\
\hline Chhattisgarh & 1.90 & 5.00 & 3.90 & 4.80 & 4.00 & 80.4 \\
\hline Goa & 0.00 & 15.4 & 20.1 & 12.2 & 7.60 & 44.6 \\
\hline Gujarat & 2.80 & 20.7 & 20.2 & 16.4 & 9.60 & 30.4 \\
\hline Haryana & 8.20 & 15.9 & 9.60 & 10.8 & 8.40 & 47.1 \\
\hline Himachal Pradesh & 0.70 & 2.00 & 5.60 & 10.3 & 10.9 & 70.5 \\
\hline Jammu \& Kashmir & 1.20 & 2.00 & 3.60 & 4.50 & 4.70 & 84.1 \\
\hline Jharkhand & 0.00 & 0.10 & 0.00 & 0.20 & 0.10 & 99.6 \\
\hline Karnataka & 8.90 & 11.7 & 5.80 & 7.00 & 6.70 & 59.9 \\
\hline Kerala & 1.30 & 1.60 & 1.60 & 1.70 & 1.70 & 92.2 \\
\hline Madhya Pradesh & 2.70 & 7.60 & 10.1 & 12.6 & 11.7 & 55.3 \\
\hline Maharashtra & 8.50 & 17.2 & 10.7 & 10.4 & 8.90 & 44.3 \\
\hline Manipur & 0.10 & 1.20 & 5.70 & 7.30 & 6.10 & 79.5 \\
\hline Meghalaya & 0.10 & 1.60 & 8.10 & 10.8 & 9.10 & 70.2 \\
\hline Mizoram & 0.00 & 0.40 & 7.70 & 7.50 & 8.60 & 75.7 \\
\hline Nagaland & 0.60 & 2.10 & 7.90 & 10.8 & 9.90 & 68.7 \\
\hline Odisha & 1.60 & 4.30 & 2.60 & 3.10 & 2.40 & 86.0 \\
\hline Punjab & 3.90 & 10.9 & 7.10 & 8.10 & 7.80 & 62.2 \\
\hline Rajasthan & 5.70 & 34.8 & 25.1 & 11.2 & 4.60 & 18.5 \\
\hline Tamil Nadu & 6.00 & 11.1 & 8.40 & 9.40 & 8.00 & 57.1 \\
\hline Telangana & 5.00 & 10.4 & 9.80 & 11.5 & 10.2 & 53.1 \\
\hline Tripura & 0.60 & 0.60 & 2.20 & 1.70 & 7.30 & 87.6 \\
\hline Uttar Pradesh & 5.40 & 12.4 & 13.5 & 13.6 & 10.7 & 44.4 \\
\hline Uttarakhand & 0.30 & 1.70 & 2.60 & 5.70 & 6.30 & 83.6 \\
\hline West Bengal & 0.00 & 0.00 & 0.00 & 0.10 & 0.00 & 99.9 \\
\hline India & 3.80 & 9.00 & 6.40 & 9.60 & 11.3 & 59.9 \\
\hline & & & & & & \\
\hline
\end{tabular}

Table 5. State-wise deficiency (\% of soil samples) status of available Fe.

each of Karnataka and Telangana, 13 districts of Odisha and 7 districts of Tamil Nadu were deficient in $\mathrm{Zn}+\mathrm{B}$. The deficiency of S + B varied widely in different states with mean value of $7.00 \%$. Relatively higher $\%$ of the soils in Jharkhand, Karnataka, Kerala, Manipur, Odisha, Uttarakhand and West Bengal state were deficient in S + B (Supplementary Figure S3). More than 20\% of soils in 6 districts each of Jharkhand and Manipur, 9 districts each of Karnataka and Kerala, 14 districts of Odisha and 5 districts of Telangana were deficient in S+B. On average, $5.80 \%$ of soils were deficient in $\mathrm{Zn}+\mathrm{Fe}$. Relatively higher $\%$ of soils of Gujarat, Karnataka, Maharashtra and Rajasthan were deficient in Zn + Fe (Supplementary Figure S4). More than 20\% of the sampled sites in 9 districts of Gujarat, 5 districts each of Madhya Pradesh and Maharashtra and 7 districts of Rajasthan had $\mathrm{Zn}+\mathrm{Fe}$ deficiency. The higher \% of soils of Goa, Jammu \& Kashmir and Rajasthan were deficient in $\mathrm{Zn}+\mathrm{Mn}$ with a national average of 3.4\% (Supplementary Figure S5). The deficiency of S + Fe, $\mathrm{Zn}+\mathrm{Cu}$ and $\mathrm{Fe}+\mathrm{B}$ were recorded in $3.30,2.80$ and $2.70 \%$ of the sampled sites, respectively and were scattered across the country (Supplementary Figure S6-S8). The deficiency S + Fe was higher in Gujarat, Haryana, Rajasthan and Uttar Pradesh.

The deficiency of 3-nutrients namely, $\mathrm{S}+\mathrm{Zn}+\mathrm{B}, \mathrm{S}+\mathrm{Zn}+\mathrm{Fe}$ and $\mathrm{Zn}+\mathrm{Fe}+\mathrm{B}$ were recorded in 2.60, 1.70 and $1.20 \%$ of soils, respectively. Relatively, the higher \% of soils in Bihar, Goa, Karnataka and Odisha were deficient in $\mathrm{S}+\mathrm{Zn}+\mathrm{B}$ (Fig. 2). S + Zn + Fe deficiency was more in soils of Gujarat, Haryana, Maharashtra and Rajasthan (Supplementary Figure S9, S10). The higher \% of the sampled sites in Bihar and Karnataka were deficient in $\mathrm{Zn}+\mathrm{Fe}+\mathrm{B}$ (Supplementary Figure S11). More than 20\% of soils in 1 district each of Bihar, Chhattisgarh, Karnataka, Madhya Pradesh and 5 districts of Odisha were deficient in $\mathrm{S}+\mathrm{Zn}+\mathrm{B}$. More than $20 \%$ of soils in 1 district each of Haryana, Karnataka, Maharashtra, and Uttar Pradesh and 2 districts each of Madhya Pradesh and Rajasthan were deficient in $\mathrm{S}+\mathrm{Zn}+\mathrm{Fe}$. More than 3-nutrients deficiencies like $\mathrm{Zn}+\mathrm{Fe}+\mathrm{Cu}+\mathrm{Mn}$ and $\mathrm{Zn}+\mathrm{Fe}+\mathrm{Cu}+\mathrm{Mn}+\mathrm{B}$ were very less and recorded in only 0.30 and $0.10 \%$ of soils, respectively. Less than $5 \%$ of the sampled sites in 13 districts of Bihar, 7 districts each of Punjab and Uttar Pradesh and 16 districts of Tamil Nadu were deficient in $\mathrm{Zn}+\mathrm{Fe}+\mathrm{Cu}+\mathrm{Mn}$. Whereas, $<5 \%$ of the sampled sites in 13 districts of Bihar, 4 districts of Punjab and 10 districts of Tamil Nadu were deficient in $\mathrm{Zn}+\mathrm{Fe}+\mathrm{Cu}+\mathrm{Mn}+\mathrm{B}$. 


\begin{tabular}{|l|l|l|l|l|l|l|}
\hline State & Acute deficient & Deficient & Latent deficient & Marginal sufficient & Adequate & High \\
\hline Andhra Pradesh & 1.30 & 5.30 & 9.00 & 11.1 & 10.1 & 63.2 \\
\hline Arunachal Pradesh & 1.40 & 3.90 & 11.8 & 19.8 & 15.8 & 47.2 \\
\hline Assam & 2.20 & 8.50 & 5.30 & 4.30 & 4.10 & 75.7 \\
\hline Bihar & 0.70 & 1.50 & 1.60 & 2.30 & 3.20 & 90.7 \\
\hline Chhattisgarh & 2.60 & 4.50 & 4.70 & 5.30 & 5.40 & 77.4 \\
\hline Goa & 3.10 & 41.2 & 22.1 & 14.4 & 6.30 & 12.9 \\
\hline Gujarat & 0.40 & 2.80 & 6.40 & 7.90 & 9.00 & 73.6 \\
\hline Haryana & 6.20 & 13.8 & 10.7 & 9.40 & 9.70 & 50.2 \\
\hline Himachal Pradesh & 1.40 & 4.80 & 8.50 & 15.0 & 13.4 & 56.8 \\
\hline Jammu \& Kashmir & 0.80 & 3.40 & 3.90 & 6.60 & 6.00 & 79.3 \\
\hline Jharkhand & 0.50 & 1.70 & 4.60 & 6.70 & 6.40 & 80.2 \\
\hline Karnataka & 2.10 & 4.80 & 7.90 & 8.60 & 9.80 & 66.7 \\
\hline Kerala & 2.60 & 3.60 & 3.80 & 4.30 & 4.60 & 81.1 \\
\hline Madhya Pradesh & 0.50 & 3.30 & 5.80 & 7.00 & 8.10 & 75.4 \\
\hline Maharashtra & 0.10 & 1.10 & 2.20 & 3.40 & 4.00 & 89.0 \\
\hline Manipur & 1.40 & 5.70 & 8.60 & 14.0 & 11.1 & 59.2 \\
\hline Meghalaya & 1.00 & 5.20 & 5.40 & 9.90 & 12.3 & 66.3 \\
\hline Mizoram & 1.50 & 6.40 & 5.10 & 16.4 & 14.4 & 56.2 \\
\hline Nagaland & 0.50 & 9.60 & 11.6 & 16.9 & 11.2 & 50.1 \\
\hline Odisha & 5.70 & 5.80 & 4.80 & 6.00 & 5.10 & 72.7 \\
\hline Punjab & 4.70 & 12.3 & 13.5 & 13.8 & 13.8 & 41.8 \\
\hline Rajasthan & 9.10 & 34.6 & 22.0 & 9.80 & 6.70 & 17.7 \\
\hline Tamil Nadu & 1.40 & 4.00 & 5.90 & 7.80 & 8.40 & 72.3 \\
\hline Telangana & 1.40 & 5.80 & 7.00 & 7.20 & 7.40 & 71.2 \\
\hline Tripura & 1.70 & 1.10 & 0.00 & 7.30 & 9.60 & 80.3 \\
\hline Uttar Pradesh & 3.10 & 13.2 & 12.1 & 9.70 & 8.30 & 53.6 \\
\hline Uttarakhand & 1.60 & 6.10 & 10.1 & 11.8 & 11.0 & 59.4 \\
\hline West Bengal & 1.50 & 2.70 & 2.10 & 2.60 & 2.80 & 88.5 \\
\hline India & 2.10 & 2.10 & 7.20 & 10.8 & 10.2 & 67.6 \\
\hline & & & & & & \\
\hline
\end{tabular}

Table 6. State-wise deficiency (\% of soil samples) status of available Cu.

\section{Discussion}

Status of available $\mathbf{S}$ and micronutrients. The concentration of available $\mathrm{S}$ in soils of different states of India varied widely (from 0.02 to $822 \mathrm{mg} \mathrm{kg}^{-1}$ ). Scherer ${ }^{29}$ also recorded wide differences in the concentrations of available $S$ soils of the world. The concentration of $\mathrm{Zn}$ (from 0.01 to $59.8 \mathrm{mg} \mathrm{kg}^{-1}$ ), B (from 0.01 to $109 \mathrm{mg} \mathrm{kg}^{-1}$ ), $\mathrm{Fe}$ (from 0.01 to $964 \mathrm{mg} \mathrm{kg}^{-1}$ ), Cu (from 0.01 to $99.2 \mathrm{mg} \mathrm{kg}^{-1}$ ) and $\mathrm{Mn}$ (from 0.01 to $483 \mathrm{mg} \mathrm{kg}^{-1}$ ) in soils of the country varied widely. Similarly, Mathew et al. ${ }^{30}$ recorded wide variations in concentration of available $\mathrm{Zn}$, Fe, $\mathrm{Mn}, \mathrm{B}$ and $\mathrm{Cu}$ in cultivated soils of Tanzania.

The mean concentrations of available $\mathrm{Zn} 2.30 \pm 1.30 \mathrm{mg} \mathrm{kg}^{-1}$, available $\mathrm{Mn} 12.2 \pm 14.4 \mathrm{mg} \mathrm{kg}^{-1}$, available Cu $1.10 \pm 0.80 \mathrm{mg} \mathrm{kg}^{-1}$ and available Fe $66.6 \pm 56.0 \mathrm{mg} \mathrm{kg}^{-1}$ were reported by Silva et al. ${ }^{31}$, in sugarcane cultivated soils of Brazil. The factors like soil types, nature of crop plants and adoption of various soil-crop management practices influence the concentrations of available $S$ and micronutrients in soils ${ }^{12,29,32,33}$. The available $S$ concentration in soils is also influenced by occurrences of plant residues, organic matter and various salts containing $\mathrm{S}^{34}$. The extent of rock weathering in soil decides the concentration of available micronutrients and $\mathrm{S}$ in soils ${ }^{12}$. The lowest concentrations of available $S$ and micronutrients prevail in the tropical soils with high levels of weathering. The availability of micronutrients in soils is primarily affected by soil parameter namely soil organic matter, soil $\mathrm{pH}$, clay content, cation exchange capacity, biological activity and redox potential. The nature of crop plants, rooting pattern, root secretions and associations of plants and microbes also affect micronutrient availability in soil and plant uptake.

Single nutrient deficiencies of available $\mathbf{S}$ and micronutrients. On an average, the concentration of available $\mathrm{S}$ in about $11.4,29.4$ and $17.8 \%$ of soils were acute deficient, deficient, and latently deficient range, respectively (Table 2). There were differences in deficiency levels of available $S$ in the districts of the states. Several districts in the states like Madhya Pradesh, Gujarat, Odisha, Rajasthan and Manipur had deficiency in available $S$ in $>50 \%$ of soils. This is mainly ascribed to variations in cultivation of S-loving crops and less or no addition of $S$ containing fertilizers. The deficiency of available $S$ could be efficiently alleviated by adopting site-specific S manipulation strategies in various soil-crop contexts. In parallel to our findings, several scholars recorded $S$ deficiency in different soil-crop contexts and responses of various crops to different $S$ doses in various states of India ${ }^{13,35-37}$. On average, the extent of deficiency (acute deficient + deficient + latent deficient) 


\begin{tabular}{|l|l|c|l|l|l|l|}
\hline State & Acute deficient & Deficient & Latent deficient & Marginal sufficient & Adequate & High \\
\hline Andhra Pradesh & 0.60 & 4.00 & 8.50 & 7.80 & 7.20 & 71.9 \\
\hline Arunachal Pradesh & 0.10 & 5.70 & 9.00 & 21.6 & 18.5 & 45.1 \\
\hline Assam & 0.10 & 0.30 & 3.40 & 6.60 & 3.40 & 86.2 \\
\hline Bihar & 0.60 & 8.70 & 14.3 & 15.1 & 12.0 & 49.4 \\
\hline Chhattisgarh & 0.80 & 3.50 & 6.40 & 5.60 & 4.70 & 79.0 \\
\hline Goa & 0.00 & 15.0 & 5.90 & 9.90 & 15.7 & 53.5 \\
\hline Gujarat & 0.10 & 2.20 & 7.60 & 10.4 & 10.3 & 69.5 \\
\hline Haryana & 1.30 & 7.40 & 12.8 & 13.3 & 12.6 & 52.7 \\
\hline Himachal Pradesh & 0.20 & 4.50 & 8.90 & 16.6 & 17.4 & 52.4 \\
\hline Jammu \& Kashmir & 3.50 & 18.7 & 16.7 & 11.4 & 9.90 & 39.7 \\
\hline Jharkhand & 0.10 & 0.30 & 0.90 & 1.50 & 2.20 & 95.0 \\
\hline Karnataka & 1.90 & 8.10 & 8.10 & 7.70 & 6.90 & 67.3 \\
\hline Kerala & 3.40 & 9.10 & 9.10 & 6.50 & 5.70 & 66.3 \\
\hline Madhya Pradesh & 0.20 & 6.10 & 10.1 & 10.5 & 9.90 & 63.2 \\
\hline Maharashtra & 0.10 & 2.00 & 5.60 & 7.30 & 7.90 & 77.2 \\
\hline Manipur & 0.00 & 10.3 & 6.50 & 13.1 & 13.4 & 56.5 \\
\hline Meghalaya & 0.10 & 5.90 & 10.7 & 12.7 & 9.90 & 60.7 \\
\hline Mizoram & 0.00 & 3.10 & 4.00 & 13.3 & 11.3 & 68.4 \\
\hline Nagaland & 0.30 & 10.8 & 9.60 & 12.2 & 12.2 & 54.8 \\
\hline Odisha & 0.60 & 4.20 & 4.50 & 4.60 & 3.90 & 82.2 \\
\hline Punjab & 7.80 & 21.2 & 26.3 & 18.7 & 10.9 & 15.2 \\
\hline Rajasthan & 5.80 & 30.5 & 17.3 & 14.6 & 10.8 & 21.0 \\
\hline Tamil Nadu & 1.70 & 12.6 & 12.7 & 9.50 & 8.10 & 55.4 \\
\hline Telangana & 0.00 & 8.40 & 9.20 & 8.60 & 7.50 & 66.2 \\
\hline Tripura & 0.60 & 0.60 & 1.10 & 6.70 & 5.60 & 85.4 \\
\hline Uttar Pradesh & 0.50 & 10.2 & 15.4 & 15.4 & 9.20 & 49.3 \\
\hline Uttarakhand & 0.20 & 4.80 & 5.60 & 7.40 & 7.70 & 74.3 \\
\hline West Bengal & 0.30 & 1.60 & 2.50 & 3.40 & 3.50 & 88.7 \\
\hline India & 1.10 & 6.00 & 10.3 & 13.2 & 9.10 & 60.4 \\
\hline & & & & & & \\
\hline
\end{tabular}

Table 7. State-wise deficiency (\% of soil samples) status of available Mn.

was $51.2 \%$ for available $\mathrm{Zn}, 44.7 \%$ for available B, $19.2 \%$ for available Fe, $11.4 \%$ for available $\mathrm{Cu}$ and $17.4 \%$ for available $\mathrm{Mn}$. In parallel to our results, there were reports of soil micronutrients deficiency in different countries of the world ${ }^{9}$. The districts of various states had different levels of micronutrients deficiency. But the almost all states of India had different levels of Zn deficiency. Most of the soils having low organic carbon content, high soil $\mathrm{pH}$, with coarse textured and calcareousness and under intense cultivation, had $\mathrm{Zn}$ deficiency. Similar to $\mathrm{Zn}$ deficiency, the deficiency of $B$ at various levels prevailed in soils of various states. However, the lateritic and limed acidic soils, calcareous and leached sandy soils had higher levels of B deficiency. The higher levels of B deficiency in eastern parts of the country are ascribed to alluvial and loess depositions and high levels of leaching in sandyloam soils. The extent of Fe deficiency was higher in states namely Gujarat, Rajasthan and Maharashtra lying in the western part of the country. Significant \% soils of the states like Uttar Pradesh, Bihar, Telangana and Karnataka had also Fe deficiency. Iron deficiency in these soils is mainly due to alkaline soil $\mathrm{Ph}$ and moisture deficit situation resulting in transformation of $\mathrm{Fe}$ from ferrous $\left(\mathrm{Fe}^{2+}\right.$ soluble) to ferric $\left(\mathrm{Fe}^{3+}\right.$ insoluble) state. The extent of $\mathrm{Cu}$ deficiency was the lowest among the studied nutrients. Thirteen districts of Haryana, Assam, Tamil Nadu, Odisha and Rajasthan had $\mathrm{Cu}$ deficiency in $>20 \%$ of soils. Calcareous, sandy textured and eluviated organic matter rich soils are the causes of Cu deficiency. The soils of the state like Haryana, Bihar, Rajasthan, Tamil Nadu, Uttar Pradesh, Telangana, Punjab and Jammu \& Kashmir had higher levels of Mn deficiency. The prime causes of Mn deficiency in these soils are prevailing moisture deficit condition, low total Mn content in soil, coarse textured and calcareous soils. There are reports of responses of different crops to micronutrients addition to various soils of India ${ }^{19,38,39}$, corroborating our findings of micronutrients deficiency in soils of various states. The farmers should go for addition of micronutrients fertilizers based on deficiency levels in soils and nature of crops and their demand, as the crop responses differ with soil-crop contexts.

Multi-nutrients deficiencies of available $\mathbf{S}$ and micronutrients. There were 2 and $>2$-nutrients deficiencies of available $S$ and micronutrients in soils different states of India. The extent of these deficiencies followed the order: $\mathrm{S}+\mathrm{Zn}(9.30 \%)>\mathrm{Zn}+\mathrm{B}(8.70 \%)>\mathrm{S}+\mathrm{B}(7.00 \%)>\mathrm{Zn}+\mathrm{Fe}(5.80 \%)>\mathrm{Zn}+\mathrm{Mn}(3.40 \%)>\mathrm{S}+\mathrm{Fe}$

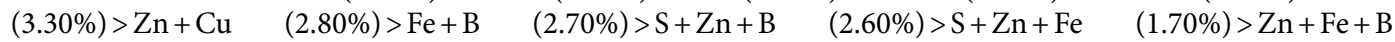
$(1.20 \%)>\mathrm{Zn}+\mathrm{Fe}+\mathrm{Cu}+\mathrm{Mn}(0.30 \%)>\mathrm{Zn}+\mathrm{Fe}+\mathrm{Cu}+\mathrm{Mn}+\mathrm{B}(0.10 \%)$ (Table 8). The different states and AERs of the country had various levels of 2 and $>2$-nutrients deficiencies of available $S$ and micronutrients. $S+Z n$ defi- 


\begin{tabular}{|c|c|c|c|c|c|c|c|c|c|c|c|c|c|}
\hline State & $S+Z n$ & $\mathrm{Zn}+\mathrm{B}$ & S+B & $\mathrm{Zn}+\mathrm{Fe}$ & $\mathrm{Zn}+\mathrm{Mn}$ & $\mathrm{S}+\mathrm{Fe}$ & $\mathrm{Zn}+\mathrm{Cu}$ & $\mathrm{Fe}+\mathrm{B}$ & $\mathbf{S}+\mathbf{Z n}+\mathbf{B}$ & $\mathrm{S}+\mathrm{Zn}+\mathrm{Fe}$ & $\mathrm{Zn}+\mathrm{Fe}+\mathrm{B}$ & $\mathrm{Zn}+\mathrm{Fe}+\mathrm{Cu}+\mathrm{Mn}$ & $\mathrm{Zn}+\mathrm{Fe}+\mathrm{Cu}+\mathrm{Mn}+\mathrm{B}$ \\
\hline Andhra Pradesh & 6.23 & 2.06 & 2.59 & 6.90 & 0.60 & 4.65 & 0.60 & 1.78 & 0.73 & 1.88 & 0.62 & 0.01 & 0.00 \\
\hline $\begin{array}{l}\text { Arunachal } \\
\text { Pradesh }\end{array}$ & 0.43 & 2.41 & 2.91 & 0.00 & 0.50 & 0.00 & 0.30 & 0.00 & 0.28 & 0.00 & 0.00 & 0.00 & 0.00 \\
\hline Bihar & 12.9 & 19.6 & 9.70 & 5.26 & 4.80 & 2.26 & 2.20 & 7.90 & 5.94 & 1.55 & 3.67 & 0.23 & 0.19 \\
\hline Chhattisgarh & 11.2 & 8.87 & 7.79 & 3.04 & 0.90 & 2.70 & 0.90 & 0.87 & 3.86 & 1.57 & 0.63 & 0.02 & 0.00 \\
\hline Goa & 17.6 & 6.32 & 9.26 & 2.21 & 10.30 & 0.59 & 2.10 & 0.59 & 5.15 & 0.44 & 0.29 & 0.00 & 0.00 \\
\hline Haryana & 6.54 & 0.75 & 1.39 & 6.59 & 2.50 & 8.70 & 3.40 & 1.10 & 0.37 & 3.02 & 0.44 & 0.34 & 0.09 \\
\hline $\begin{array}{l}\text { Himachal } \\
\text { Pradesh }\end{array}$ & 0.15 & 3.08 & 0.97 & 0.22 & 0.80 & 0.25 & 0.30 & 0.50 & 0.14 & 0.03 & 0.09 & 0.00 & 0.00 \\
\hline $\begin{array}{l}\text { Jammu \& } \\
\text { Kashmir }\end{array}$ & 4.44 & 0.00 & 0.00 & 0.54 & 7.04 & 0.43 & 0.19 & 0.00 & 0.00 & 0.20 & 0.00 & 0.07 & 0.00 \\
\hline Jharkhand & 7.38 & 8.40 & 25.9 & 0.00 & 0.20 & 0.00 & 0.10 & 0.00 & 4.40 & 0.00 & 0.00 & 0.00 & 0.00 \\
\hline Manipur & 5.17 & 9.41 & 17.4 & 0.87 & 2.40 & 0.07 & 0.60 & 0.93 & 2.52 & 0.00 & 0.43 & 0.00 & 0.00 \\
\hline Meghalaya & 0.55 & 1.31 & 3.37 & 0.07 & 0.30 & 0.76 & 0.10 & 0.62 & 0.14 & 0.00 & 0.07 & 0.00 & 0.00 \\
\hline Mizoram & 0.22 & 1.11 & 3.76 & 0.00 & 0.00 & 0.22 & 0.20 & 0.22 & 0.00 & 0.00 & 0.00 & 0.00 & 0.00 \\
\hline Nagaland & 0.50 & 2.19 & 0.80 & 0.40 & 0.30 & 0.60 & 0.10 & 0.60 & 0.00 & 0.00 & 0.30 & 0.00 & 0.00 \\
\hline Odisha & 18.0 & 20.3 & 25.3 & 2.53 & 1.30 & 1.67 & 2.50 & 2.25 & 11.4 & 1.01 & 1.04 & 0.01 & 0.00 \\
\hline Punjab & 6.15 & 2.83 & 4.04 & 4.64 & 7.00 & 4.90 & 2.70 & 1.82 & 1.01 & 1.70 & 0.68 & 0.48 & 0.15 \\
\hline Rajasthan & 29.9 & 0.57 & 1.16 & 23.3 & 22.5 & 16.9 & 7.80 & 0.06 & 0.30 & 11.8 & 0.02 & 2.03 & 0.00 \\
\hline Tamil Nadu & 5.81 & 13.1 & 2.45 & 7.71 & 5.30 & 0.88 & 9.10 & 2.00 & 1.68 & 0.71 & 1.38 & 0.66 & 0.10 \\
\hline Telangana & 6.96 & 8.92 & 9.60 & 4.68 & 0.80 & 4.48 & 0.60 & 4.10 & 2.26 & 1.22 & 1.30 & 0.00 & 0.00 \\
\hline Tripura & 0.00 & 0.56 & 0.00 & 0.00 & 0.00 & 0.00 & 0.00 & 0.00 & 0.00 & 0.00 & 0.00 & 0.00 & 0.00 \\
\hline
\end{tabular}

Table 8. Per cent of the soils deficient in multi-nutrients in different states of India. $S$ available sulphur, $Z n$ available zinc, $B$ available boron, $F e$ available iron, $C u$ available copper, $M n$ available manganese.

ciency was prevalent in $>15 \%$ of soils of Odisha, Rajasthan, Madhya Pradesh and Goa. This was also prevailed in higher extent in soils of AER 5, 8, 9, 10 and 13. The deficiency of $\mathrm{Zn}+\mathrm{B}$ was prevalent at greater extent in soils of Odisha, Tamil Nadu, Karnataka and Bihar falling in the AER 5, 8, 12 and 13. The soil of the states namely Jharkhand, Odisha, Kerala, West Bengal and Uttarakhand had higher levels of S $\mathrm{B}$ deficiency. The levels of $\mathrm{Zn}+\mathrm{Fe}$ deficiency were more in Rajasthan, Gujarat, Karnataka and Maharashtra and AER 2, 5, 6 and 8. As discussed earlier, this spatial variations in prevalence of multi-nutrients deficiencies are ascribed to different soils, crops, climates and soil-crop manipulation practices. These multi-nutrients deficiencies could be alleviated by production, distribution and application of $S$ and micronutrients containing customized fertilizers prepared based on prevailing nutrient deficiencies in various AER, states and districts of the country. This will help to a greater extent in maintaining soil health, having sustainable crop production and better quality of $\mathrm{crops}^{40,41}$. The information from the study could suitably be used by the different stake holders (policy makers, planners and fertilizer industries) associated with production and distribution of $S$ and micronutrients containing straight and customized fertilizers to various targeted areas of the country. There are responses of different crops to the addition of available customized fertilizers in different parts of India ${ }^{42-44}$. However, there is an urgent necessity for development, distribution and application of $\mathrm{S}$ and micronutrients containing straight and customized fertilizers for different areas of the country, based on the current knowledge on $S$ and micronutrients deficiency. It will be useful to a greater extent for alleviating $\mathrm{S}$ and micronutrients deficiencies in soils, maintaining soil health, sustainable crop production, increased crop quality and better health of animals and human being.

\section{Conclusions}

The present study highlighted the existence of wide variability in available $\mathrm{S}$ and micronutrients status in cultivated soils of various states of India. On average, the extent of deficiencies (considering acute deficient, deficient and latent deficient together) of the studied nutrients in soils of the country followed the order: available $S>$ available $\mathrm{Zn}>$ available $\mathrm{B}>$ available $\mathrm{Fe}>$ available $\mathrm{Mn}>$ available $\mathrm{Cu}$. The higher $\%$ of soils in Kerala, Odisha and West Bengal were acute deficient in available S and available B. Whereas, the higher \% of soils in Rajasthan, Madhya 


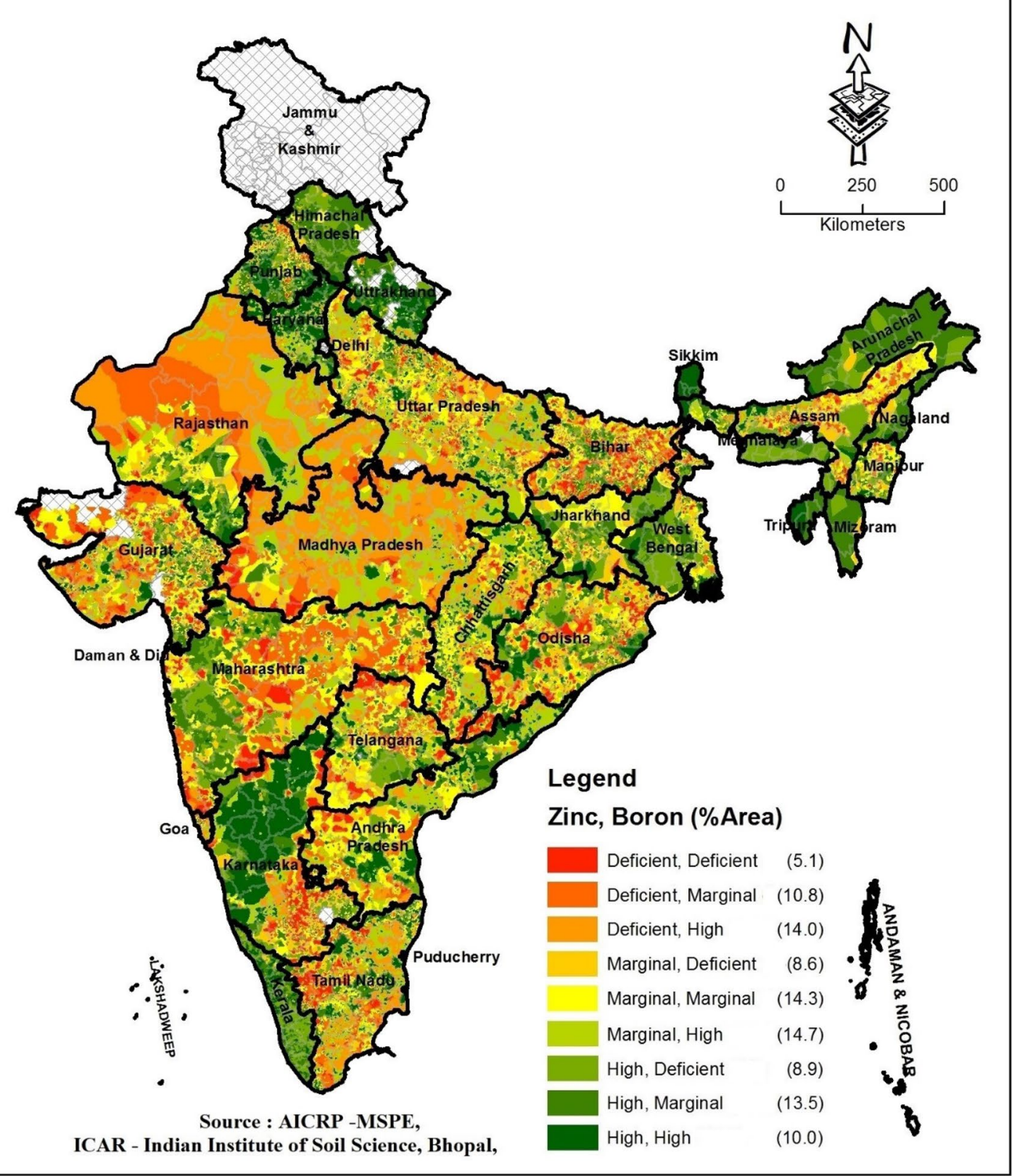

Figure 1. Spatial distribution of $\mathrm{Zn}+\mathrm{B}$ deficiency in different states of India (The figure has been prepared using ArcGIS software (version 10.5.1), Environmental Systems Research Institute, Redlands, California).

Pradesh, Goa, Odisha and Karnataka were acute deficient in available Zn. The existence of 2 or $>2$ nutrients deficiencies of available $S$ and micronutrients is restricted to limited areas of different districts of various states. On average, the levels of deficiencies of $S+Z n, Z n+B, S+B$ and $Z n+F e$ were higher than the deficiencies of other multi-nutrients. This knowledge could be used for area-specific $S$ and micronutrients management for better crop production and crop quality. Further, district- and state-specific $S$ and micronutrients based customized fertilizers could be developed and distributed based on the information generated from the study. However, there is a need for periodic assessment of available $S$ and micronutrients status in cultivated soils of various states, at 3-5 years interval, as the status of these nutrients change with soil-crop management practices. Further, development of kriged distribution maps of available $S$ and micronutrients (using geostatistical tools) for different districts, states and at country level is needed for preparing site-specific nutrient management strategies. This type of study needs to be carried out in cultivated soils pf other parts of world for effective $\mathrm{S}$ and micronutrients needed for substantiable crop production, crop quality and good health of soils, crops, animals and human being. 


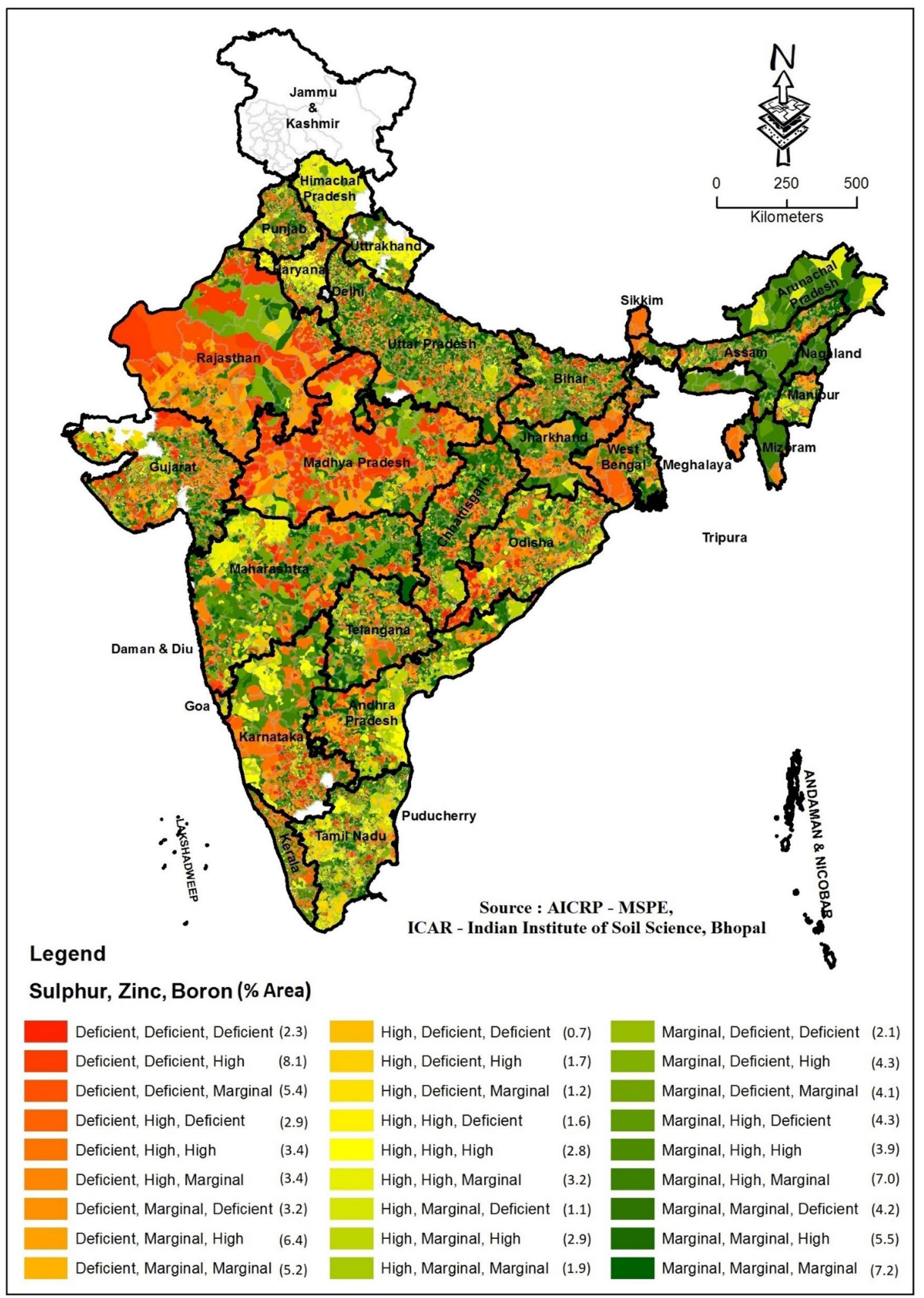

Figure 2. Spatial distribution of $\mathrm{S}+\mathrm{Zn}+\mathrm{B}$ deficiency in different states of India (The figure has been prepared using ArcGIS software (version 10.5.1), Environmental Systems Research Institute, Redlands, California). 


\section{Data availability}

The data are available from the corresponding author upon reasonable request.

Received: 11 June 2021; Accepted: 17 September 2021

Published online: 05 October 2021

\section{References}

1. Brevik, E. C. et al. Soil and human health: Current status and future needs. Air Soil Water Res. 13, 1-23. https://doi.org/10.1177/ 1178622120934441 (2020).

2. Marschner, P. Marschner's Mineral Nutrition of Higher Plants (Academic Press, 2020). https://doi.org/10.1016/C2009-0-63043-9.

3. Singh, B. \& Schulze, D. G. Soil minerals and plant nutrition. Nat. Educ. Knowl. 6, 1 (2015).

4. Cogger, C. \& Brown, S. Soil formation and nutrient cycling. In Sowing Seeds in the City (eds Brown, S. et al.) (Springer, 2016). https://doi.org/10.1007/978-94-017-7453-6_2.

5. White, P. J. \& Brown, P. H. Plant nutrition for sustainable development and global health. Ann. Bot. 105, 1073-1080. https://doi. org/10.1093/aob/mcq085 (2010).

6. Shukla, A. K., Behera, S. K., Pakhre, A. \& Chaudhari, S. K. Micronutrients in soils, plants, animals and humans. Indian J. Fertil. 14, 30-54 (2018).

7. Khurana, M. P. S., Sadana, U. S. \& Singh, B. Sulfur nutrition of crops in the Indo-Gangetic plains of south Asia. In Sulfur: A Missing Link Between Soils, Crops, and Nutrition (ed. Jez, J.) 11-24 (Argon. Monogr. 50. ASA, CSSA, SSSA, 2008).

8. Piotrowska-Dlugosz, A., Siwik-Ziomek, A., Dlugosz, J. \& Gozdowski, D. Spatio-temporal variability of soil sulfur content and arylsulfatase activity at a conventionally managed arable field. Geoderma 295, 107-118. https://doi.org/10.1016/j.geoderma.2017. 02.009 (2017).

9. Alloway, B. J. Micronutrient Deficiencies in Global Crop Production (Springer, 2008). https://doi.org/10.1007/978-1-4020-6860-7.

10. Shukla, A. K., Behera, S. K., Satyanarayana, T. \& Majumdar, K. Importance of micronutrients in Indian agriculture. Better Crops South Asia 11, 6-10 (2019).

11. Kihara, J., Bolo, P., Kinyua, M., Rurinda, J. \& Pikki, K. Micronutrient deficiencies in African soils and the human nutritional nexus: opportunities with staple crops. Environ. Geochem. Health 42, 3015-3033. https://doi.org/10.1007/s10653-019-00499-w (2020).

12. Fageria, N. K., Baligar, V. C. \& Clark, R. B. Micronutrients in crop production. Adv. Agron. 77, 185-250. https://doi.org/10.1016/ S0065-2113(02)77015-6(2002).

13. Shukla, A. K. \& Behera, S. K. All India research project on micro- and secondary nutrients and pollutant elements in soils and plants: Research achievements and future thrusts. Indian J. Fertil. 15, 522-543 (2019).

14. Manzeke, G. M. et al. Fertilizer management and soil type influence grain zinc and iron concentration under contrasting smallholder cropping systems in Zimbabwe. Sci. Rep. 9, 6445. https://doi.org/10.1038/s41598-019-42828-0 (2019).

15. Shukla, A. K. \& Behera, S. K. Biofortification for overcoming zinc and iron malnutrition in Indian population: Current research status and way forward. Indian J. Fertil. 16, 1262-1276 (2020).

16. Shah, F. \& Wu, W. Soil and crop management strategies to ensure higher crop productivity within sustainable environments. Sustainability 11, 1485. https://doi.org/10.3390/su11051485 (2019).

17. Behera, S. K. et al. Spatial variability of some soil properties varies in oil palm (Elaeis guineensis Jacq.) plantations of west coastal area of India. Solid Earth 7, 979-993. https://doi.org/10.5194/se-7-979-2016 (2016).

18. Shukla, A. K. et al. Spatial variability of soil micronutrients in the intensively cultivated Trans-Gangetic Plains of India. Soil Till. Res. 163, 282-289. https://doi.org/10.1016/j.still.2016.07.004 (2016).

19. Shukla, A. K. et al. Pre-monsoon spatial distribution of available micronutrients and sulphur in surface soils and their management zones in Indian Indo-Gangetic Plain. PLoS ONE 15, e0234053. https://doi.org/10.1371/journal.pone.0234053 (2020).

20. Steffan, J. J., Brevik, E. C., Burgess, L. C. \& Cerda, A. The effect of soil on human health: An overview. Eur. J. Soil Sci. 69, 159-171. https://doi.org/10.1111/ejss.12451 (2018).

21. Behera, S. K. et al. Establishing management zones of soil sulphur and micronutrients for sustainable crop production. Land Degrad. Dev. 32(13), 3614-3625. https://doi.org/10.1002/ldr.3698 (2021).

22. Soil Survey Staff. Keys to Soil Taxonomy (USDA-Natural Resources Conservation Service, 2014).

23. NBSSLUP. National Bureau of Soil Survey and Land Use Planning. Available online: https://www.nbsslup.in/assets/uploads/clinks/ Delineating\%20Agro-Ecological\%20Regions.pdf (accessed on 20 July 2021)(2021).@@@

24. Gelfand, A. E. \& Schliep, E. M. Spatial statistics and Gaussian processes: A beautiful marriage. Spat. Stat. 18, 86-104. https://doi. org/10.1016/j.spasta.2016.03.006 (2016).

25. Williams, C. H. \& Steinbergs, A. Soil sulphur fractions as chemical indices of available sulphur in some Australian soils. Aust. J. Agric. Res. 10, 340-352. https://doi.org/10.1071/AR9590340 (1959).

26. Lindsay, W. L. \& Norvell, W. A. Development of a DTPA soil test for zinc, iron, manganese and copper. Soil Sci. Soc. Am. J. 42, 421-448. https://doi.org/10.2136/sssaj1978.03615995004200030009x (1978).

27. Gupta, U. C. A simplified method for determining hot-water soluble boron in podzol soils. Soil Sci. 103, 424-428 (1967).

28. SAS Institute. The SAS System for Windows (Release 9.2. Cary, NC: SAS Inst., 2011).

29. Sherer, H. W. Sulfur in soils. J. Plant Nutr. Soil Sci. 172, 326-335. https://doi.org/10.1002/jpln.200900037 (2009).

30. Mathew, M. M., Majule, A. E., Marchant, R. \& Sinclair, F. Variability of soil micronutrients concentration along the slopes of Mount Kilimanjaro, Tanzania. Appl. Environ. Soil Sci. https://doi.org/10.1155/2016/9814316 (2016).

31. Silva, R. C. F., Silva, F. B. V., Biondi, C. M., Nascimento, C. W. A. \& Oliveira, E. C. A. Assessing the content of micronutrients in soils and sugarcane in different pedogeological contexts of northeastern Brazil. Revista Brasileira de Ciencia do Solo 43, e0180228. https://doi.org/10.1590/18069657rbcs20180228 (2019).

32. White, J. G. \& Zasoski, R. J. Mapping soil micronutrients. Field Crops Res. 60, 11-26. https://doi.org/10.1016/S0378-4290(98) 00130-0 (1999).

33. Rengel, Z. Availability of Mn, Zn and Fe in the rhizosphere. J. Soil Sci. Plant Nutr. 15, 397-409. https://doi.org/10.4067/S0718-95162 015005000036 (2015).

34. Dick, W. A., Kost, D. \& Chen, L. Availability of sulfur to crops from soil and other sources. In Sulfur: A Missing Link Between Soils, Crops and Nutrition (ed. Jez, J.) (American Society of Agronomy, Crop Science Society of America, Soil Science Society of America, 2008). https://doi.org/10.2134/agronmonogr50.c5.

35. Singh, M. V. \& Behera, S. K. All India Coordinated Research Project of Micro- and Secondary Nutrients and Pollutant Elements in Soils and Plants-A profile. Research Bulletin No. 10. All India Coordinated Research Project of Micro- and Secondary Nutrients and Pollutant Elements in Soils and Plants, IISS, Bhopal, 1-57 (2011).

36. Aulakh, M. S. Crop responses to sulphur nutrition. In Sulphur in Plants (eds Abrol, Y. P. \& Ahmad, A.) (Springer, 2003). https:// doi.org/10.1007/978-94-017-0289-8 19.

37. Singh, V. K. et al. Status of available sulfur in soils of north-western Indo-Gangetic plain and western Himalayan region and responses of rice and wheat to applied sulfur in farmer's fields. Agric. Res. 4, 76-92. https://doi.org/10.1007/s40003-015-0149-7 (2015). 
38. Takkar, P. N., Chhibba, I. M. \& Mehta, S. K. Twenty Years of Coordinated Research on Micronutrients in Soils and Plants (Indian Institute of Soil Science, 1989).

39. Shukla, A. K. \& Behera, S. K. Micronutrient fertilizers for higher productivity. Indian J. Fertil. 8, 100-117 (2012).

40. Tiwari, K. N. Relevance of customized fertilizers in the era of multi-nutrient deficiency. Indian J. Fertil. 6, 76-86 (2010).

41. Majumdar, S. \& Prakash, N. B. Prospects of customized fertilizers in Indian agriculture. Curr. Sci. 115, 242-248. https://doi.org/ $10.18520 / \mathrm{cs} / \mathrm{v} 115 / \mathrm{i} 2 / 242-248$ (2018).

42. FAI. Speciality Fertilizers and Micronutrient Statistics 2019-20 (The Fertiliser Association of India, New Delhi, 2020).

43. Dwivedi, S. K. Meshram MREffect of customized fertilizer on productivity and nutrient uptake of rice (Oryza sativa). Indian J. Agron. 59, 247-250 (2014).

44. Mudalagiriyappa, B., Raghavendra Goud, B., Ramachandrappa, B. K. \& Nanjappa, H. V. Influence of customized fertilizers on growth and yield of Finger Millet Eleusine coracana (L.) Gaertn in Alfisols of southern India. Indian J. Dryland Agric. Res. Dev. 30, 50-54. https://doi.org/10.5958/2231-6701.2015.00007.X (2015).

\section{Acknowledgements}

The authors thank the Indian Council of Agricultural Research, New Delhi for supporting the study through All India Coordinated Research Project on Micro and Secondary Nutrients in Soils and Plants. The authors acknowledge their colleagues who extended logistic and technical support during the study.

\section{Author contributions}

All of the authors contributed to the design of the study. A.K.S., S.K.B., S.D. and C.P. collected the samples, relevant data and conducted analysis. A.K.S. and S.K.B wrote the first draft. A.K.S., S.K.B, A.K.P., C.S.R., S.D. S.K.C. and A.K.S. edited and revised the manuscript.

\section{Funding}

The study was funded by Indian Council of Agricultural Research, New Delhi.

\section{Competing interests}

The authors declare no competing interests.

\section{Additional information}

Supplementary Information The online version contains supplementary material available at https://doi.org/ 10.1038/s41598-021-99040-2.

Correspondence and requests for materials should be addressed to S.K.B.

Reprints and permissions information is available at www.nature.com/reprints.

Publisher's note Springer Nature remains neutral with regard to jurisdictional claims in published maps and institutional affiliations.

(c) (i) Open Access This article is licensed under a Creative Commons Attribution 4.0 International License, which permits use, sharing, adaptation, distribution and reproduction in any medium or format, as long as you give appropriate credit to the original author(s) and the source, provide a link to the Creative Commons licence, and indicate if changes were made. The images or other third party material in this article are included in the article's Creative Commons licence, unless indicated otherwise in a credit line to the material. If material is not included in the article's Creative Commons licence and your intended use is not permitted by statutory regulation or exceeds the permitted use, you will need to obtain permission directly from the copyright holder. To view a copy of this licence, visit http://creativecommons.org/licenses/by/4.0/.

(c) The Author(s) 2021 